University of Chicago Law School

Chicago Unbound

Journal Articles

Faculty Scholarship

1987

\title{
The Constitution in the Supreme Court: Civil Rights and Liberties, 1930-1941
}

David P. Currie

Follow this and additional works at: https://chicagounbound.uchicago.edu/journal_articles

Part of the Law Commons

\section{Recommended Citation}

David P. Currie, "The Constitution in the Supreme Court: Civil Rights and Liberties, 1930-1941," 1987 Duke Law Journal 800 (1987).

This Article is brought to you for free and open access by the Faculty Scholarship at Chicago Unbound. It has been accepted for inclusion in Journal Articles by an authorized administrator of Chicago Unbound. For more information, please contact unbound@law.uchicago.edu. 


\title{
THE CONSTITUTION IN THE SUPREME COURT: CIVIL RIGHTS AND LIBERTIES, 1930-1941
}

\author{
David P. CurRIE*
}

This is the latest in Professor Currie's continuing series on the historical development of constitutional doctrine. In this article Professor Currie surveys the major decisions of the Supreme Court between 1930 and 1941 in the area of criminal procedure, civil rights and civil liberties. In the area of criminal procedure, Professor Currie concludes that in deciding what procedures were required or forbidden by due process, historical inquiry was displaced by a fundamental-rights test. In the area of civil liberties, Professor Currie concludes that the Court made modest progress. Finally, Professor Currie concludes that the Court's most important civil liberties work during the period was in the area of freedom of expression, assembly and religion.

Amid the thunder of the great economic controversies that destroyed economic due process, the contract clause and the concept of limited federal power, ${ }^{1}$ the Supreme Court of the 1930 s quietly began to work on the agenda of the future: criminal procedure, civil rights and civil liberties.

\section{Criminal Procedure}

In 1856 , the Court had defined due process of law in essentially historical terms in Murray's Lessee v. Hoboken Land \& Improvement Co. ${ }^{2}$ Unless the challenged procedure conflicted with other provisions of the Constitution itself, the question was whether it was in accord with "those settled usages and modes of proceeding existing in the common and statute law of England, before the emigration of our ancestors, and which are shown not to have been unsuited to their civil and political condition by having been acted on by them after the settlement of this country."3 Applying this test, the Court upheld a statute providing for summary collection of money that a customs collector owed the United States, because such a procedure was sanctioned by practice both in England and

* Harry N. Wyatt Professor of Law, University of Chicago. I should like to thank Geoffrey R. Stone for valuable criticism and suggestions.

1. See Currie, The Constitution in the Supreme Court: The New Deal, 1931-40, 54 U. CHI. L. REv. 504, 507-16 (1987) [hereinafter Hughes $\Pi$.

2. 59 U.S. (18 How.) 272 (1856).

3. Id. at 277 . 


\section{in the Colonies. ${ }^{4}$}

Any implication of the converse proposition-that all procedural rights sanctioned by history were indispensable elements of due process-had been rejected in Hurtado v. California ${ }^{5}$ in 1884. It was true that "a process of law, which is not otherwise forbidden, must be taken to be due process of law, if it can show the sanction of settled usage both in England and in this country; but it by no means follows that nothing else can be due process of law."6 Historical acceptance was a sufficient but not a necessary condition of constitutionality; due process required only such established procedures as were "fundamental."7

On this basis, indictment, jury trial and the privilege against selfincrimination had all been held to be outside the scope of the due process requirement and thus inapplicable to the states. ${ }^{8}$ The essence of due process, the Court said, was adequate notice and a hearing before an unbiased and unintimidated judge with jurisdiction. ${ }^{9}$ Under Chief Justice Hughes, however, while downplaying the historical dimension of the inquiry, the Court significantly expanded the list of due process requirements.

4. Id. at 281-86. See D. Currie, The Constitution in the Supreme Court: The First HUNDRED YEARS 272, 276 n.304 (1985) (expressing doubts whether the due process clauses should have been construed to limit legislative power at all).

5. 110 U.S. 516 (1884).

6. Id. at 528 .

7. Id. at 535; D. CuRRIE, supra note 4 , at 366-67.

8. Hurtado, 110 U.S. at 538 (indictment); Maxwell v. Dow, 176 U.S. 581, 604-05 (1900) (12member jury); Twining v. New Jersey, 211 U.S. 78, 113-14 (1908) (self-incrimination); see also Walker v. Sauvinet, 92 U.S. 90, 92-93 (1876) (due process does not embrace the right to jury trial).

9. See, e.g., Roller v. Holly, 176 U.S. 398, 409 (1900) (notice); Hovey v. Elliott, 167 U.S. 409, 413-15 (1897) (hearing); Tumey v. Ohio, 273 U.S. 510, 523-32 (1927) (unbiased judge); Moore v. Dempsey, 261 U.S. 86, 90-91 (1923) (mob domination); Pennoyer v. Neff, 95 U.S. 714, 733 (1878) (dictum) (jurisdiction). Chief Justice Hughes wrote to refine the notion of bias in United States v. Wood, 299 U.S. 123, 136-51 (1936). In Wood he held that absent a showing of actual bias the presence of government employees on a criminal jury was forbidden by neither history nor justice and thus offended neither due process nor the sixth amendment right to an impartial jury. Both Wood, 299 U.S. at 142-49, and Patton v. United States, 281 U.S. 276, 288 (1930) (Sutherland, J.), which allowed the defendant to waive a 12 -member jury with government consent, stressed that the principle Hurtado had ennnciated in the due process context applied to the explicit criminal jury provisions as well; only the "essential" elements of the common-law right were preserved. Although in Wood Hnghes argued that a similar test had been employed in applying the seventh amendment provision that jury findings be reviewed only "according to the rules of the common law," 299 U.S. at 143-44 (quoting Baltimore \& Carolina Line v. Redman, 295 U.S. 654, 657 (1935)), the decisions under that provision seemed to follow history much more closely, as the language of the clause itself suggested, see, e.g., Dimick v. Schiedt, 293 U.S. 474, 486-88 (1935) (Sutherland, J.) (5-4 decision striking down an additur provision for avoiding a new trial for inadequate damages if the defendant agreed to pay more than the jury had awarded, because the practice had been unknown in England in 1791); Baltimore \& Carolina Line, 295 U.S. at 659-61 (upholding a provision for jndgment notwithstanding the verdict after reservation of ruling on motion for directed verdict, becanse similar practice had existed at common law). 
A. Powell v. Alabama.

The first example of this expansion was Powell v. Alabama, ${ }^{10}$ a 1932 decision arising out of the notorious prosecution of seven young blackswho came to be known as the "Scottsboro boys"-for the rape of two white girls on a freight train. Without reaching claims of discrimination in jury selection and mob domination of the trial, the Court concluded that due process required the state to permit the defendants to appear by counsel and to provide legal assistance for those unable to obtain their own. ${ }^{11}$

The first conclusion was relatively easy. Although English courts had afforded no right to counsel in serious criminal cases at the time of emigration, the English practice had been repudiated in the Colonies and thus was not sanctioned by history in the sense of Murray's Lessee. Moreover, given the helplessness of the layman accused of a crime, the defect was fundamental in the Hurtado sense: "The right to be heard would be, in many cases, of little avail if it did not comprehend the right to be heard by counsel." 12 Finally, although one of the grounds given in Hurtado for holding that clue process did not include the right to an indictment had been that a contrary holding would make redundant the specific fifth amendment requirement of a federal grand jury, Justice Sutherland rightly observed in Powell that later cases had shown such an overlap not determinative; due process must in any event be given its natural meaning. ${ }^{13}$

The requirement that the state provide counsel was another story. Sutherland nowhere asserted that colonial practice had required the government to pay for an attorney; most of the provisions he cited merely recognized the right to employ one. ${ }^{14}$ Rather, the basis for this decision was simply that the right to appointed counsel, "at least in cases like the present," was "fundamental." Every state required the appointment of counsel at least in capital cases. If this universal practice did not "establish" the right, it surely "reflect[ed]" it. In any event, to condemn an incompetent defendant to death without assigned counsel "would be lit-

10. 287 U.S. 45 (1932) (Sutherland, J., over dissents by Butler and McReynolds, JJ.).

11. Id. at 68-71. The dissents argued that counsel had actually been provided. Id. at 74 .

12. Id. at 68-69.

13. See id. at 60-71 (citing for the last point decisions holding that due process prohibited the states from infringing freedom of speech or press or taking property without compensation).

14. See id. at 61-65. The one apparent exception was a Pennsylvania statute paraphrased as providing "that in capital cases learned counsel should be assigned to the prisoners." It is possible that other provisions such as those granting simply a "right to counsel" had been construed to require the state to provide attorneys, but Sutherland did not say they had. 
tle short of judicial murder."15

Unlike the conclusion that due process required an opportunity to employ counsel, the requirement that the state provide counsel seemed to turn the Hurtado test on its head. Hurtado had introduced the fundamental-rights test as a means of denying rights historically afforded; Powell employed it to grant rights historically denied. ${ }^{16}$

\section{B. Later Cases.}

Mooney v. Holohan ${ }^{17}$ and Brown v. Mississippi, ${ }^{18}$ while adding that knowing use of perjured testimony and reliance on a coerced confession were also fundaniental flaws, suggested a narrow interpretation of the new test. Like a trial without counsel or doininated by a mob, trial on the basis of coerced or perjured testimony was a mere "pretense." 19 In effect, the Court was saying, the defendants had received no hearing at all; and the right to a hearing had always been an essential elenient of due process. ${ }^{20}$ Thus, even if there was no historical support for the particular requirements announced in these cases, they night all be viewed as implicit in the historical and fundainental right to a "hearing," and the Hurtado test arguably had not been perverted after all.

The trouble with this reasoning is that, at least with regard to the right to assigned counsel, it seems to contradict the historical understanding of what constituted a hearing. The issue of mob domination could have been fitted within the historical requirenent of an inipartial arbiter, and the common law had excluded coerced confessions. ${ }^{21}$ No departure froin history was thus required to outlaw them. It was other-

15. Id. at 72-73. The central argument of the opinion seems equally applicable to any serious criminal case, although the Court's appropriate insistence that it was deciding only the case before it and its observation that counsel was necessary "above all" because the defendants stood "in deadly peril of their lives," id. at 71, furnished a handhold for a narrower reading. Nor should the requirement that counsel be provided at state expense be taken to expand the holding of Truax v. Corrigan, 257 U.S. 312 (1921), that a state deprived a person of life or property by its failure to affirmatively protect him, 257 U.S. at 328-30; in Powell the state, by virtue of its criminal prosecution, was actively seeking to deprive the defendant of his life, 287 U.S. at 46. See Currie, The Constitution in the Supreme Court: 1921-1930, 1986 DukE L.J. 65, $71-76$ (discussing Truax) [hereinafter Taft]; Currie, Positive and Negative Constitutional Rights, 53 U. CH1. L. REv. 864, 873-74 (1986).

16. See Easterbrook, Substance and Due Process, 1982 Sup. CT. REv. 85, 106 ("Hurtado . . . give[s] no support to judicial augmentation of historically recognized procedures.").

17. 294 U.S. 103,112 (1935) (per curiam) (perjured testimony).

18. 297 U.S. $278,285-86$ (1936) (Hughes, C.J.) (confession obtained by physical torture).

19. In Chambers v. Florida, 309 U.S. 227, 238-39 (1940), Justice Black applied Brown to confessions obtained by six days of repeated questioning. There was no suggestion that the same reasoning would apply to a voluntary confession, which would render the trial an even more foregone conclusion; the distinction may lie in the realm of waiver.

20. See, e.g., Powell, 287 U.S. at 68.

21. See W. LaFave \& J. ISraEl, Criminal Procedure 264-65 (1985). 
wise, however, with the right to assigned counsel. The materials cited in Powell suggested that no such right was implicit in the historical concept of a hearing.

In any event, the language of the opinions suggests that the question whether an alleged right was "fundamental" had basically displaced the historical inquiry it had been designed to accompany. In 1937, Justice Cardozo's famous opinion in Palko v. Connecticut, 22 permitting the state to appeal a conviction for a lesser crime than had been sought, lent force to this conclusion by announcing that due process embraced all requirements of the Bill of Rights that were "implicit in the concept of ordered liberty." 23 Even long-established procedures, it seemed, were now subject to scrutiny for their compatibility with contemporary notions of fair play. ${ }^{24}$

Once Hurtado had concluded that the framers did not mean to burden us with unnecessary anachronisms, one might plausibly have argued that they would not have wanted to subject us to unfair ones either. It was true that the particular vice of holding all common-law rights protected was not something that legislatures could correct. ${ }^{25}$ Nothing in the Constitution, however, appeared to inhibit legislatures from affording additional rights. It might be argued that those intent on protecting existing fundamental rights from legislative interference would not have trusted legislators to remedy past inadequacies, though the open-endedness of the resulting judicial authority might have furnished a basis of

22. 302 U.S. 319 (1937) (over unexplained dissent of Butler, J.).

23. Id. at 325. See also id. at 328 ("Is that kind of double jeopardy to which the statute has subjected [the defendant] a hardship so acute and shocking that our polity will not endure it? ... The answer surely must be 'no.' "); Snyder v. Massachusetts, 291 U.S. 97, 115 (1934) (Cardozo, J., over dissent by Roberts, J., with Brandeis, Sutherland and Butler, JJ., concurring in the dissent) (holding that the defendant need not be present when a jury viewed the scene of the crime: "There can be no sound solution without an answer to the question whether in the particular conditions exhibited by the record the enforced absence of the defendant is so flagrantly unjust that the Constitution of the United States steps in to lorbid it.").

24. See Nutting, The Supreme Court, the Fourteenth Amendment and State Criminal Cases, 3 U. CHI. L. REV. 244, 254 (1936) (arguing that under decisions of the Hughes period any state measure offended due process "the effect of which is to deprive the accused of what the Supreme Court of the United States may regard as a fair trial"); $c f$. Milliken v. Meyer, 311 U.S. 457, 463 (1940) (Douglas, J.) (undertaking no historical analysis in holding that civil jurisdiction of state court based upon out-of-state service on domiciliary of forum state satisfied "traditional notions of fair play and substantial justice" and noting that "[t]he state which accords him privileges and affords protection to him and his property by virtue of his domicile may also exact reciprocal duties"); Ohio Bell Tel. Co. v. Public Utils. Comın'n, 301 U.S. 292, 300 (1937) (Cardozo, J.) (undertaking no historical analysis in holding that administrative reliance on information not revealed to the parties for possible rebuttal denied a litigant "[t]he fundamentals of a trial").

25. Hurtado, 110 U.S. at 529 ("[T] o hold that [settled usage] is essential to due process of law, would be to deny every quality of the law but its age, and to render it incapable of progress or improvement."). 
distinction. What was most striking was that the Court made no attempt to explain or to justify the momentous change it appeared to be making. ${ }^{26}$

\section{CIVIL Rights}

The central purpose of the Civil War amendments, as the Court stressed in the Slaughterhouse Cases, ${ }^{27}$ was to put an end to state discrimination against blacks. ${ }^{28}$ Under Chief Justices Waite and Fuller, the Supreme Court had condemned the exclusion of blacks from juries and of Chinese from the laundry business and established that equality did not preclude separation. ${ }^{29}$ Under Fuller and White, it had struck down peonage and grandfather clauses and held that racial zoning, despite its apparent conformity with the separate-but-equal doctrine, deprived landowners of property without due process of law. ${ }^{30}$ Under Chief Justice Taft, it had held that the state could not exclude blacks from voting in political primaries. ${ }^{31}$ In contrast to the whirlwind of activity that had characterized fourteenth amendment litigation in other fields, that was about all the Court had to say about race before 1930 .

\section{A. Juries, Grandfathers and Schools.}

Under Chief Justice Hughes, the Court made modest progress. The Justices exhibited what seemed to be an increased willingness to scrutinize records for proof of discrimination against blacks in the selection of juries. $^{32}$ Lane v. Wilson ${ }^{33}$ belatedly struck down Oklahoma's effort to

26. See Easterbrook, supra note 16, at 108-09.

27. 83 U.S. (16 Wall.) $36,67-72,81$ (1873).

28. See D. CuRR1E, supra note 4, at 342-51 (discussing the Slaughterhouse Cases).

29. See, e.g., Strauder v. West Virginia, 100 U.S. 303 (1880) (black jurors); Yick Wo v. Hopkins, 118 U.S. 356 (1886) (Chinese laundries); Plessy v. Ferguson, 163 U.S. 537 (1896) (upholding segregated trains); Pace v. Alabama, 106 U.S. 583 (1883) (criminal statute separately defining interracial offense not racially discriminatory where same punishment prescribed for both races). See generally D. CuRRIE, supra note 4, at 383-90 (discussing Strauder, Yickwo and Pace); Currie, The Constitution in the Supreme Court: The Protection of Economic Interests, 1889-1910, 52 U. CHI. L. Rev. 324, 369-70 (1985) [hereinafter Fuller $I$ (discussing Plessy).

30. See, e.g., Bailey v. Alabama, 219 U.S. 219 (1911) (peonage); Clyatt v. United States, 197 U.S. 207 (1905) (peonage); Guinn v. United States, 238 U.S. 347 (1915) (grandfather clause); Buchanan v. Warley, 245 U.S. 60 (1917) (racial zoning). See generally Currie, The Constitution in the Supreme Court: 1910-192 I, 1985 DuKE L.J. 1111, 1132-38 [hereinafter White] (discussing Bailey, Guinn and Buchanan).

31. See, e.g., Nixon v. Herndon, 273 U.S. 536 (1927) (white primary). See generally Taft, supra note 15, at 70-71 (discussing Nixon).

32. See, e.g., Smith v. Texas, 311 U.S. 128 (1940) (Black, J.); Pierre v. Louisiana, 306 U.S. 354 (1939) (Black, J.); Hale v. Kentucky, 303 U.S. 613 (1938) (per curiam); Hollins v. Oklahoma, 295 U.S. 394 (1935) (per curiam); Norris v. Alabama, 294 U.S. 587 (1935) (Hughes, C.J.); Nutting, supra note 24, at 250-51. The Chief Justice made clear in Norris that Supreme Court review in these cases extended to state court findings of fact where necessary to ensure that constitutional rights had not 
evade the grandfather clause decision. Missouri ex rel. Gaines v. Canada $^{34}$ put teeth in the requirement that separate facilities be equal by holding that a state with a law school of its own could not require a black to go beyond its borders to study law, even if it paid his expenses.

Chief Justice Hughes easily could have based this last conclusion on the convincing argument that a legal education outside the state was objectively disadvantageous, ${ }^{35}$ but he selected a broader ground. Whether or not opportunities elsewhere were as good as those in Missouri,

[t]he white resident is afforded legal education within the State; the negro resident having the same qualifications ... must go outside the State to obtain it. That is a denial of the equality of legal right to the enjoyment of the privilege which the State has set up, and the provision for the payment of tuition fees in another State does not remove the discrimination. ${ }^{36}$

Earlier cases, both in and out of the area of race, had held that it was sufficient, for fourteenth amendment purposes, if one class of persons was treated as well as another, even if its members were afforded different privileges. ${ }^{37}$ By declining to follow this principle, the Court seemed to lay the foundation for an attack on the doctrine of separation itself, which Hughes distinguished on the unpersuasive ground that "the obligation of the State to give the protection of equal laws can be performed only where its laws operate, that is, within its own jurisdiction." 38

been denied. 294 U.S. at 589-90. See also Pierre, 306 U.S. at 358 ("[W] [Wen a claim is properly asserted ... that a citizen whose life is at stake has been denied the equal protection of his country's laws on account of his race, it becomes our solemn duty to make independent inquiry and determination of the disputed facts ....").

33. 307 U.S. 268 (1939) (Frankfurter, J., over dissents by McReynolds and Butler, JJ.). The new provision required those who had not voted in 1914 to register within 12 days or forever be disenfranchised. "The practical effect ... was to accord to the members of the negro race ... not more than 12 days within which to reassert constitutional rights which this Court found in the Guinn case to have been improperly taken from them." Id. at 276.

34. 305 U.S. 337 (1938) (Hughes, C.J., over a dissent by McReynolds, J.).

35. See id. at 349 (noting "the opportunities for the particular study of Missouri law and for the observation of the local courts" and adverting to "the difference in distances to be traveled"-whose impact in terms of personal and professional contacts, it should be added, is not covered by payment of travel expenses.).

36. Id. at 349-50.

37. See, e.g., Plessy v. Ferguson, 163 U.S. 537 (1896) (separate railroad cars for different races); Missouri v. Lewis, 101 U.S. 22 (1879) (separate courts for different regions of state with one region having no right of appeal to the state's Supreme Court); D. CuRRIE, supra note 4, at 388-89 \& n.145 (discussing various meanings of equality).

38. 305 U.S. at 350. See R. MCCloskey, The American Supreme Court 211 (1960) ("The Missouri decision signalized a new judicial mood toward Negro rights."). 


\section{B. White Primaries.}

Equally interesting was the 1932 decision in Nixon v. Condon ${ }^{39}$ that a black could not be denied the right to vote in a primary election in Texas. An earlier decision so holding had been relatively easy, for the state itself had excluded blacks from the primary by statute. ${ }^{40}$ Thereafter, however, the statute had been amended to permit each party's State Executive Committee to prescribe qualifications for participation in its primaries. ${ }^{41}$ It was contended with some force that because it was now a party rule that excluded blacks, the state was no longer responsible and that only the state was forbidden to deny equal protection. ${ }^{42}$

The Court's rejection of this argument rested on the fact that the statute had vested in the State Executive Committee a power to act on behalf of the party. The party itself had given its committee no such authority. Thus, the Court concluded, the committee had acted "not as the delegates of the party, but as the delegates of the State."43

The possible implications of this reasoning were sweeping. If a special authorization to make rules for the party was enough to make the committee a state agent, the same might arguably be said of general laws recognizing the power of a majority of the members to do so. This could mean that every act of a state-chartered corporation might be held to be that of the state. ${ }^{44}$

Three years later, in Grovey v. Townsend, ${ }^{45}$ the Court unanimously recoiled from this implication, holding that a resolution of the Democratic party convention excluding blacks was not state action despite the existence of state laws providing for the election of convention delegates. Nor was it enough to make the state responsible for the party's discrimination, wrote Justice Roberts, that the state extensively regulated primary elections, that a state officer had refused the petitioner his ballot in reliance on the party resolution, or that "in Texas nomination by the Democratic party [was] equivalent to election." 46

39. 286 U.S. 73 (1932).

40. Nixon v. Herndon, 273 U.S. 536, 541 (1927).

41. See 286 U.S. at 82 .

42. See id. at 83; id. at 89-106 (McReynolds, Van Devanter, Sutherland, and Butler, JJ., dissenting).

43. Id. at 85 .

44. In response one might argue that the authority of a majority to govern the party came not from the law of voluntary associations, but from the agreement of the members, and that the state was no more responsible for this decision than for any other private agreement it might recognize as legally binding.

45. 295 U.S. $45,53-54$ (1935) (Roberts, J.).

46. Id. at 54. For a contemporaneous argument to the contrary, see Evans, Primary Elections and the Constitution, 32 MiCH. L. REV. 451, 462 (1934). 
In making such a nice distinction between the two cases, the Court foreshadowed future difficulties in drawing the line between public and private discrimination. It also made clear that the Nixon holding had been much less revolutionary than it might at first have appeared. For the time being, the southern states remained at liberty to render the fifteenth amendment hollow by allowing the dominant political party to exclude blacks from the only election that mattered. ${ }^{47}$

\section{Civil Liberties}

Apart from the economic cases, the most important developments in constitutional law during the 1930s concerned the first amendment freedoms of expression, assembly and religion.

\section{A. Applicability to the States.}

The first amendment, the Court had held, applied only to the federal government-as its language and history made abundantly clear. ${ }^{48}$ In Meyer v. Nebraska, ${ }^{49}$ however, the Court had declared in dictum that "the right of the individual . . . to worship God according to the dictates of his own conscience" was among the "libert[ies]" protected against state infringement by the fourteenth amendment's due process clause. ${ }^{50}$ In Gitlow v. New York, ${ }^{51}$ the majority had expressly assumed, without deciding, that the same was true of freedom of speech and the press; in Whitney v. California, ${ }^{52}$ it had rejected a challenge to a state law without alluding to the question. Fiske v. Kansas ${ }^{53}$ had actually overturned a

47. Another device commonly employed to disenfranchise blacks survived judicial scrutiny when the Court upheld a statute condilioning the right to vote on payment of a poll tax in Breedlove v. Suttles, 302 U.S. 277 (1937) (Butler, J.). The complaining party in this case was white, and no argument of disguised racial motive was addressed. "Exaction of payment before registration," the Court said, "undoubtedly serves to aid collection from electors desiring to vote." Id. at 283. A later generation of judges, still without entering the thicket of legislative motives, would find this an inadequate reason for discriminating among otherwise eligible voters. See Harper v. Virginia Bd. of Elections, 383 U.S. 663 (1966). The exception of nonvoting women from the poll tax, Justice Butler added, was justified by the "burdens necessarily borne by them for the preservation of the race." Breedlove, 302 U.S. at 282.

48. Permoli v. New Orleans, 44 U.S. (3 How.) 589, 609 (1845) (free exercise of religion). The first amendment provides that "Congress shall make no law ...." U.S. CONST. amend. I (emphasis added); $c f$. Barron v. Baltimore, 32 U.S. (7 Pet.) 243 (1833) (holding that the fifth amendment does not apply to the states). See generally D. CuRRIE, supra note 4, at 189-93 (discussing Barron and the applicability of the amendments to the states).

49. 262 U.S. 390 (1923).

50. Id. at 399. See also Taft, supra note 15 , at 80-82.

51. 268 U.S. 652,666 (1925). Holmes, in dissent, flatly asserted that the Court's assumption vas eorrect. Id. at 672 .

52. 274 U.S. 357 (1927). Brandeis, in a separate concurring opinion, reaffirmed the answer Holmes had given in Gitlow. Id. at 373.

53. 274 U.S. 380 (1927). 
state conviction that had been attacked on speech grounds without saying whether the basis of decision was freedom of expression or a procedural requirement of evidence to support the charge. ${ }^{54}$ Under Chief Justice Hughes, the Court turned these intimations into clear holdings and extended them. ${ }^{55}$

Before his first term was over, Hughes wrote for the Court in Stromberg $v$. California ${ }^{56}$ to strike down a state law as an infringement of the freedom of speech. He relied wholly on precedent to show that this guarantee applied to the states: "It has been determined that the conception of liberty under the due process clause of the Fourteenth Amendment embraces the right of free speech."57 Cited for this conclusion were Gitlow, Whitney and Fiske, none of which had addressed the issue explicitly. Thus the important and debatable conclusion that the fourteenth amendment protected speech against state abridgement entered the law without ever having been explictly justified in a majority opinion.

Two weeks later, in Near v. Minnesota, ${ }^{58}$ Hughes cited the same three precedents, as well as Stromberg, as having established that freedom of the press was likewise protected agamst the states, though only Gitlow had so much as mentioned the press. This time he offered something resembling a reason for the conclusion: "It was found impossible to conclude that this essential personal liberty of the citizen was left unprotected by the general guaranty of fundamental rights of person and property."59

Justice Sutherland was more explicit in Grosjean v. American Press Co. ${ }^{60}$ in 1936. Powell v. Alabama, he said, had held that due process made those Bill of Rights provisions that were "fundamental" applicable to the states, and speech and press freedoms were as fundamental as the right to counsel. Thus, in determining what liberties the clause protected, the Court, without explanation, employed the test it had developed for determining what process was due when those liberties were taken away.

54. See G. Stone, L. Seidman, C. Sunstein \& M. Tushnet, Constitutional Law 966 (1986). These decisions are discussed in Taft, supra note 15, at 82-91.

55. See Green, Liberty Under the Fourteenth Amendment, 27 WASH. U.L.Q. 497, 515-16 (1942).

56. 283 U.S. 359 (1931).

57. Id. at 368 . Justices McReynolds and Butler, dissenting, did not think it necessary to reach the question. Id. at 370-76.

58. 283 U.S. 697 (1931) ("It is no longer open to doubt that the liberty of the press, and of speech, is within the liberty safeguarded by the due process clause of the Fourteenth Amendment from invasion by state action.").

59. Id. at 707.

60. 297 U.S. $233,243-44$ (1936). 
De Jonge v. Oregon ${ }^{61}$ added freedom of assembly to the list of incorporated freedoms in 1937. "The right of peaceable assembly," wrote the Chief Justice, "is a right cognate to those of free speech and free press and is equally fundamental." 62 Finally, in Cantwell v. Connecticut ${ }^{63}$ in 1940, the Court for the first time invalidated state action as an infringement of religious freedom, citing a speech case for the overbroad conclusion that "[t]he fundamental concept of liberty embodied in [the Fourteenth] Amendment embraces the liberties guaranteed by the First Amendment." 64

The best explanation for all this remained that given by Justice Brandeis in his concurring opinion in Whitney: once "liberty" had been misconstrued to include freedom of contract, there was no reason to exclude other rights that were equally important. ${ }^{65}$ Thus, the application of the first amendment to the states rested on the same sandy foundation that supported Lochner $v$. New York; 66 yet the Court vigorously extended the former as it dismantled the latter, with little attention to the apparent inconsistency. ${ }^{67}$

\section{B. Political Dissent.}

Most of the freedom of expression cases decided before 1930 had involved political dissent, which Justice Brandeis had suggested lay at the heart of the first amenclment. ${ }^{68}$ In these decisions, despite varying formulations of the governing standard, the Court had seemed to exercise considerable restraint in reviewing both state and federal convictions for

61. 299 U.S. 353 (1937).

62. Id, at 364 .

63. 310 U.S. 296 (1940).

64. Id. at 303 (citing Schneider v. State, 308 U.S. 147, 160 (1939)). Justice Butler had declared religious liberties protected in equally conclusory terms in Hamilton v. Regents of the Univ. of Cal., 293 U.S. 245, 262 (1934), in which the challenged requirement was upheld.

65. 274 U.S. 357,373 (1927).

66. 198 U.S. 45 (1905).

67. As an original matter there was a stronger though not conclusive case for incorporation of the first amendment through the privileges or immunities clause of the fourteenth amendment, but that argument had been decisively rejected in The Slaughterhouse Cases half a century before. See D. CURRIE, supra note 4, at 342-51, 363-64 (discussing the Slaughterhouse cases, 83 U.S. (16 Wall.) 36 (1872), and subsequent decisions).

68. See Whitney, 274 U.S. at 375 (Brandeis, J., concurring) ("Those who won our independence ... valued liberty both as an end and as a means.... They believed that freedom to think as you will and to speak as you think are means indispensable to the discovery and spread of political truth ...."); see also United States v. Carolene Prods. Co., 304 U.S. 144, 152-53 n.4 (1938) (Stone, C.J.) (assimilating "restraints upon the dissemination of information" to "legislation which restricts those political processes which can ordinarily be expected to bring about repeal of undesirable legislation"); Palko v. Connecticut, 302 U.S. 319, 327 (1937) (Cardozo, J.) (describing freedom of speech and thought as "the matrix, the indispensable condition, of nearly every other form of freedom"). 
speech thought to be subversive. ${ }^{69}$ The 1930s witnessed the blossoming of speech protections outside this traditional field, as we shall see; but they also produced three decisions suggesting a significant trend toward stricter scrutiny of punishment for allegedly subversive expression.

1. Herndon v. Lowry. The least revolutionary of these decisions, Herndon v. Lowry, ${ }^{70}$ was the last. Herndon had been convicted of the statutory offense of attempting to incite insurrection. ${ }^{71}$ Gitlow seemed to establish that such a statute was constitutional whether or not a particular attempt was likely to succeed. ${ }^{72}$ Gitlow, however, had been found responsible for distributing a revolutionary "manifesto."73 Unlike the four dissenters, ${ }^{74}$ Justice Roberts reasonably, if rather strictly, concluded that Herndon's mere possession of somewhat similar pamphlets did not prove he had distributed them. ${ }^{75}$

On this view of the evidence, Herndon had been convicted for mere solicitation of members for the Commumist Party. That, Roberts concluded, was not enough to prove him guilty of incitement to insurrection, and thus the conviction was unconstitutional. ${ }^{76}$ This technique had been employed in 1927 in Fiske v. Kansas, ${ }^{77}$ which struck down a conviction for incitement to violent overthrow of government for want of evidence that the organization for which the defendant solicited members had in fact advocated violence. Fiske had said only that such a conviction "unwarrantably infring[es] the liberty of the defendant in violation of the due process clause."78 Herndon, without explanation and without citing Fiske, based its conclusion squarely on freedom of speech and assembly. ${ }^{79}$

This clarification was an important step, and the Court's willingness to scrutinize the record for inadequate evidence, like that in Fiske, con-

69. See cases cited supra notes 51-53; White, supra note 30, at 1145-55 (discussing Schenck v. United States, 249 U.S. 47 (1919) and Abrams v. United States, 250 U.S. 616 (1919)).

70. 301 U.S. 242 (1937).

71. Id. at 243.

72. See Gitlow, 268 U.S. at $669-70$ (upholding conviction under statute outlawing advocacy of forcible overthrow of government).

73. Id. at 655-59.

74. Herndon, 301 U.S. at 274-75 (Van Devanter, McReynolds, Sutherland, and Butler, JJ., dissenting).

75. Id. at $259-60$.

76. Id. at 261 ("His membership in the Communist Party and his solicitation of a few members wholly fails to establish an attempt to incite others to insurrection.").

77. 274 U.S. $380,386-87$ (1927).

78. Id. at 387.

79. The Court stated:

If the evidence fails to show that he did so incite, then, as applied to him, the statute unreasonably limits freedom of speech and freedom of assembly .... In these circum- 
trasted sharply with its refusal to do so in Whitney. ${ }^{80}$ The Court made clear, however, that it was not saying the state could not make mere solicitation for the Communist Party a crime. Since the legislature had not done so, there was no occasion for the broad deference to legislative judgment that had been practiced in Gitlow. ${ }^{81}$ Even if the legislature had specifically prohibited such solicitation, Roberts warned, the punishment inflicted would have to "find its justification in a reasonable apprehension of danger to organized government"; for this additional limitation he cited the earlier case of De Jonge v. Oregon. ${ }^{82}$

2. De Jonge v. Oregon. De Jonge had been convicted for assisting in the conduct of a meeting called by the Communist Party. ${ }^{83}$ In contrast to Herndon, the legislature had explicitly made this conduct a crime; 84 the Court unanimously held that by doing so the legislature itself had gone too far.

There was nothing in the record in De Jonge to indicate that the meeting had been called to further subversive goals. For all that appeared, the defendant might have been convicted for assisting in the conduct of a meeting "to discuss the tariff, or the foreign policy of the Government, or taxation, or relief, or candidacies for the offices of President." 85 It was one thing to outlaw actual incitement to revolution, as in Gitlow, or knowing assistance in setting up a revolutionary organization, as in Whitney. ${ }^{86}$ Mere assistance in the conduct of a communist-run meeting was another matter. "The question ... is not as to the auspices under which the meeting is held but as to its purpose; not as to the relations of the speakers, but whether their utterances transcend the bounds of the freedom of speech which the Constitution protects." 87 Because "peaceable assembly for lawful discussion cannot be made a crime," the

stances, to make membership in the party and solicitation of members for that party a criminal offense . . is an unwarranted invasion of the right of freedom of speech.

301 U.S. at 259.61. The Court added that the statute itself was unconstitutionally vague because it "does not furnish a sufficiently ascertainable standard of guilt." Id. at 261.

80. 274 U.S. at 367 (dismissing an objection to statutorily required finding of knowledge of an organization's subversive goals as "involving ... no constitutional question whatever," but softening the blow by observing that the jury finding had been "sustained by the Court of Appeals over the specific objection that it was not supported by the evidence"); $c f$. Norris v. Alabama, 294 U.S. 587, 590 (1935) (aggressive approach to review of state court factfinding relevant to issue of discrimination in jury selection).

81. Herndon, 301 U.S. at 256, 260.

82. Id. at 258.59 (citing De Jonge v. Oregon, 299 U.S. 353 (1937)).

83. 299 U.S. at 357.

84. Id. at 356-57.

85. Id. at 363 .

86. Id.

87. Id. at 365 . 
statute was invalid as applied. ${ }^{88}$

As Hughes and Roberts argued, the results in De Jonge and Herndon were not necessarily irreconcilable with Gitlow or Whitney. They suggested, however, a new spirit of aggressiveness in reviewing both legislative and judicial findings affecting expression that was more remimiscent of the separate views of Holmes and Brandeis in the earlier cases than of the majority opinions they were protesting.

3. Stromberg v. California. Still more novel and far-reaching was the earlier decision in Stromberg $v$. California, ${ }^{89}$ which invalidated a state statute forbidding the exhibition of a red flag as a symbol of opposition to government. As in De Jonge, a decision of the legislature itself was struck down, but the reason was far more radical.

Though the Court did not advert to it, there was an important threshold question whether freedom of expression extended beyond the spoken and written word to embrace visual symbols like the red flag. In light of the first amendment's apparent purpose of encouraging the communication of ideas, a powerful argument could have been made for treating every method of communication as speech, ${ }^{90}$ leaving the problem of unreasonably obstructive or dangerous means of communication to be worked out along the lines soon to be developed for regulating the time, place and manner of expression in words. ${ }^{91}$ Far from disputing that the display of a red flag was speech, the state had proscribed it only for the message it conveyed; and the Court took the state at its word.92

The flag in Stromberg had been raised at a children's camp in connection with a pledge of allegiance "to the worker's red flag, and to the cause for which it stands; one aim throughout our lives, freedom for the working class." 93 The Court might easily have held, as in De Jonge, that the statute could not validly be applied to such an innocuous event as that shown by the record. Yet Chief Justice Hughes selected a broader

88. Id.

89. 283 U.S. 359 (1931).

90. See Henkin, The Supreme Court, 1967 Term-Foreword: On Drawing Lines, 82 HARv. L. REV. 63, 79-80 (1968) ("If it is intended as expression, if in fact it communicates, . . it is 'speech.'").

91. See Clark v. Community for Creative Non-Violence, 468 U.S. 288 (1984) (upholding ban on sleeping in park as applied to protest on behalf of homeless); Nimmer, The Meaning of Symbolic Speech Under the First Amendment, 21 UCLA L. Rev. 29, 61 (1973); Alfange, Free Speech and Symbolic Conduct: The Draft-Card Burning Case, 1968 SUP. CT. REv. 1, 24-26; infra notes 122-52 and accompanying text.

92. See Nimmer, supra note 91 , at 45 ("The state should not be heard to deny the actor's claim that the conduct in question was intended to communicate if the state acted in order to suppress such a communication.").

93. 283 U.S. at 362 . 
ground. The statutory language was so sweeping, he wrote, that it might be applied to "peaceful and orderly opposition to government by legal means" and thus to "conduct which [like the peaceable assembly in De Jonge] the State could not constitutionally prohibit."94 A statute "so vague and indefinite as to permit the punishment" of such protected conduct, Hughes concluded without explanation, was "invalid on its face."95

Thus, both Stromberg and De Jonge held that the state legislatures had invalidly punished constitutionally protected conduct. There, however, the resemblance between the two decisions ends. De Jonge set aside a conviction because the record did not show the defendant had done anything that could constitutionally be punished; Stromberg did so without examining the record because it would be unconstitutional to apply the statute to someone else. 96

Even more striking was the contrast with Gitlow. In Gitlow the Court had allowed punishment of an act assumed to be innocuous because other prohibited acts might be dangerous; in Stromberg it forbade punishment of an act assumed to be dangerous because other prohibited acts might be innocuous. Not a word was said to explain why the invalidity of the statute as applied to others was relevant in Stromberg, or why the Court sometimes took one approach and sometimes another.

Gitlow, however, had not denied that a statute that reached too broadly would be unconstitutional. Because it had found the challenged law valid, the Court in Gitlow had not had to face the severability question that Stromberg posed: did an overbroad law have to be struck down even as to activities that could validly have been forbidden, or could it be cut down to constitutional size?

Stromberg's unexplained conclusion that the statute could not be pared down echoed the decision in United States $v$. Reese, ${ }^{97}$ which had aborted a prosecution for infringing voting rights on racial grounds because the statute improperly forbade all interference with voting. ${ }^{98}$ This

94. Id. at 369 (citing the state court opinion below, People v. Mintz, 62 Cal. App. 788, 290 P. $93(1930)$ ).

95. Id. at 369-70. Justices McReynolds and Butler argued in dissent that the validity of this provision was not properly before the Court. Id. at 370-76.

96. The condemnation of the law as "vague and indefinite" reminds one of earlier decisions outside the speech field striking down vague laws on due process grounds for failure to give fair warning of what they forbade. E.g., United States v. L. Cohen Grocery Co., 255 U.S. 81, 89-93 (1921). In Stromberg, however, the Court spoke not of fair warning, but of the impact of the statute on the constitutionally protected right of political discussion. In the earlier cases, moreover, there was no suggestion that one defendant was released because the law could not constitutionally be applied to another. The overlap between the two doctrines is discussed in Note, The Void-ForVagueness Doctrine in the Supreme Court: A Means to an End, 109 U. PA. L. REV. 67 (1960).

97. 92 U.S. 214 (1875).

98. Id. at 221-22. 
holding seemed peculiar in itself and has since ceased to be generally followed. ${ }^{99}$ Moreover, Reese involved a federal statute, Stromberg a state one. One would expect severability in the latter case to be a question of state law. ${ }^{100}$

Much later the Court would explain that the overbreadth doctrine, first applied to speech cases in Stromberg, served to protect persons from being deterred from protected expression because of the risk that it might be found punishable. ${ }^{101}$ If Hughes had something like that in mind he kept it to himself, and he left his novel approach entirely unexplained.

\section{The Press.}

1. Near v. Minnesota. Herndon, De Jonge and Stromberg all involved punishment for past expression. Near v. Minnesota ${ }^{102}$ involved an effort to prevent expression in the future.

Following a series of colorful articles charging public officials with failure to enforce laws against organized crime, a state court had enjoined the defendants from publishing, distributing or possessing any newspaper that was "malicious, scandalous and defamatory."103 In a 1931 opinion by Chief Justice Hughes, the Court held the statute authorizing the injunction unconstitutional as applied. The difficult question in the past, he said, had been whether freedom of speech was protected against subsequent punishments; history showed that protection against 95.

99. See, e.g., United States v. Raines, 362 U.S. 17, 24 (1960); D. CURRIE, supra note 4, at 393-

100. In commerce clause cases, for example, the Court had frequently struck down the application of state statutes to particular transactions without suggesting that they could no longer be applied at all. See, e.g., Dahnke-Walker Milling Co. v. Bondurant, 257 U.S. 282, 292-93 (1921) (state may not require foreign corporation engaged solely in interstate commerce to qualify to do business). In other cases, moreover, the Court had expressly refused to consider whether a state statute that could validly be applied to the case at bar would be invalid if applied to someone else. See, e.g., Yazoo \& M. R.R. v. Jackson Vinegar Co., 226 U.S. 217, 219-20 (1912) (A provision requiring prompt settlement of claims for lost freight was upheld as applied: "this court must deal with the case in hand and not with imaginary ones."). But see Monaghan, Overbreadth, 1981 SUP. CT. REV. 1, 6-14 (distinguishing Yazoo as a case that reached the Supreme Court "without any authoritative construction of the statute by the state courts" and arguing that the Court regularly invalidates on their face statutes overbroad as construed, because "a litigant . . . can insist that his conduct be judged in accordance with a rule that is constitutionally valid.").

101. See Gooding v. Wilson, 405 U.S. 518, 521 (1972) ("This is deemed necessary because persons whose expression is constitutionally protected may well refrain from exercising their rights for fear of criminal sanctions provided by a statute susceptible of application to protected expression."); see also Note, The First Amendment Overbreadth Doctrine, 83 HARv. L. Rev. 844, 853 (1970) (discussing "chilling effect" of overbroad coverage). In equal protection cases it is immaterial whether the conduct in question could have been prohibited by a different statute, but that is because the vice toward which that clause was directed is inequality. A different argument is necessary to justify facial review of statutes challenged on first amendment grounds.

102. 283 U.S. 697 (1931).

103. Id. at 704,706 . 
"previous restraints" was at the heart of the first amendment. ${ }^{104}$

In what sense, however, was the injunction a previous restraint? It was true that, though based upon the finding that the defendant had published offensive material before, ${ }^{105}$ the injunction prohibited future publications on pain of contempt. A criminal statute embodying the same prohibition, however, would likewise have prohibited future conduct, on pain of criminal sanctions; and such a statute would be taken to impose a threat of subsequent punishment, not a previous restraint. The Court did not say in what respect the injunction posed a greater threat to freedom of expression than would an ordinary criminal law.

The previous restraint condemned by Blackstone and others on whom the Court relied had consisted of a licensing system forbidding publication without prior official approval. ${ }^{106}$ Licensing not only prevents publication of punishable material; it delays publication of inoffensive material as well, as the innocuousness of the publication is no defense to the separate offense of publishing without a license. In a criminal prosecution based upon the offensiveness of the publication itself, in contrast, the defendant can escape punishment by showing that the publication was not prohibited. The principal vice of a previous restraint thus seems to lie in the fact that it delays the publication of protected materials until after their legality las been determined. ${ }^{107}$

In this light, equating an injunction with licensing begins to make sense. Unlike a criminal law, an injunction generally must be obeyed until set aside even if it was invalidly entered, and protected speech may therefore be delayed. ${ }^{108}$

104. Id. at 713-15.

105. See id. at 735-36 (Butler, J., joined by Van Devanter, McReynolds, and Sutherland, JJ., dissenting).

106. See, c.g., id. at 734-35 (Butler, J., dissenting) (quoting J. STORY, COMMENTARIES ON THE CONSTITUTION § 1882 (1833)); see also Pound, Equitable Relief Against Defamation and Injuries to Persollality, 29 HARV. L. REV. 640, 651 (1916) (arguing that the rule against previous restraints ought not to be taken as precluding injunctions against defamation, because history shows the "main purpose" to be "freedom from a regime of general censorship and license of printing"). For a challenging panoply of arguments why injunctions are less harmful to legitimate speech interests than licensing, see Mayton, Toward a Theory of First Amendment Process: Injunctions of Speech, Subsequent Punishnent, and the Costs of the Prior Restraint Doctrine, 67 CORNELL. L. REV. 245 (1982).

107. See Redish, The Proper Role of the Prior Restraint Doctrine in First Amendment Theory, 70 VA. L. REV. 53, 55-58 (1984). The purpose of the previous restraint rule is thus related to that of Stromberg's overbreadth doctrine: both prevent certain methods of suppressing even those publications that constitutionally may be prohibited, in order to remove impediments to the publication of protected materials. See G. Stone, L. Seidman, C. Sunstein \& M. Tushnet, supra note 54, at $1036,1046$.

108. See United States v. United Mine Workers, 330 U.S. 258, 293-95 (1947) (stressing overriding need for respect for judicial orders); Walker v. City of Birmingham, 388 U.S. 307, 315 (1967) (applying this rule in freedom of expression case); see also Barnett, The Puzzle of Prior Restraint, 29 STAN. L. REv. 539, 552 (1977) (discussing Walker). 
It is true that the injunction appealed in Near had been issued only after a trial. 109 It had not, however, been stayed pending appellate review; and therefore it too posed the risk of delaying the publication of information that ultimately might be held to be protected. It is also true that in a contempt proceeding for violating the injunction the defendants could have defended on the ground that the material published had not been "malicious, scandalous or defamatory" within the meaning of the order. They could not have done so, however, on the ground that those terms were unconstitutionally broad, or that conduct falling within them was constitutionally protected. Thus the effect of the injunction, like that of a licensing law, seemed to be to postpone the publication of arguably protected material until after a final determination of its acceptability; the Court was right to treat it as a previous restraint.

Even previous restraints, the Chief Justice hastened to add, were not always forbidden.

No one would question but that a government might prevent actual obstruction to its recruiting service or the publication of the sailing dates of transports or the number and location of troops. On similar grounds, the primary requirements of decency may be enforced against obscene publications. The security of the community life may be protected against incitements to acts of violence and the overthrow by force of orderly government. The constitutional guaranty of free speech does not "protect a man from an injunction against uttering words that may have all the effect of force." These limitations are not applicable here. Nor are we now concerned with questions as to the extent of authority to prevent publications in order to protect private rights according to the principles governing the exercise of the jurisdiction of courts of equity. ${ }^{110}$

Several of these examples seemed to be, as Hughes argued, "exceptional cases," in which the interests requiring previous restraints could fairly be described as overwhelming. Obscenity, however, hardly seems to fall into that category. ${ }^{111}$ The list of exceptions thus left the reader wondering what was left of the supposedly powerful principle against previous restraints and why the publication in question fell within it.

109. 283 U.S. at 735 (Butler, J., dissenting) ("The restraint authorized is only in respect of continuing to do what has been duly adjudged to constitute a nuisance."). Upon filing of the complaint, however, the trial court had also entered an order temporarily forbidding circulation. Id. at 704-05.

110. Id. at 716 (citations omitted).

111. The traditional justification for punishing obscenity is the perception that its social value is slight. See Chaplinsky v. New Hampshire, 315 U.S. 568, 572 (1942) ("[T] he lewd and obscene, the profane, the libelous, and the insulting or 'fighting' words . . arc no essential part of any exposition of ideas, and are of such slight social value as a step to truth that any benefit that may be derived from them is clearly outweighed by the social interest in order and morality."). The risk of delaying protected publications may be an acceptable cost if the publication arguably endangers national security; it is harder to justify if the publicaton is arguably worthless. 
As in Herndon v. Lowry, Van Devanter, McReynolds, Sutherland and Butler dissented. ${ }^{112}$ It is interesting that the four Justices most zealous to discover infringements of economic liberties under the due process clause were the least willing to find invasions of freedom of expression under the same provision.

2. Grosjean v. American Press Co. The press won another great victory in Grosjean v. American Press Co., ${ }^{113}$ in which Justice Sutherland wrote for the whole bench in holding invalid a Louisiana tax measured by the gross advertising receipts of newspapers distributing over 20,000 copies weekly. Taxes on newspapers, Sutherland noted, had been subject to vehement opposition in England and in the Colonies because they were a means of suppressing criticism of the government; they were therefore at the heart of the guarantee of freedom of the press. ${ }^{114}$

The tax in question was especially suspicious in that it applied only to papers of large circulation, "with the plain purpose of penalizing the publishers and curtailing the circulation of a selected group of newspapers."115 The thrust of the opinion, however, was broader. Although nothing the Court said was "to suggest that the owners of newspapers are immune from any of the ordinary forms of taxation for support of the government," special taxes on the press alone were impermissible. ${ }^{116}$

To the extent that he relied upon an unexpressed purpose to suppress publication, ${ }^{117}$ Sutherland seemed to evince an unusual willingness to look behind plausible revenue measures in search of impermissible motives. ${ }^{118}$ Apart from motive, however, he seemed on sound ground in terms both of history and of underlying policy in concluding that discriminatory taxes had a forbidden deterrent effect on the press whether or not they picked favorites among publishers. ${ }^{119}$

112. 283 U.S. at 723-38. See supra notes 70-82 and accompanying text (discussing Herndon).

113. 297 U.S. 233 (1936).

114. Id. at 246-49 (echoing the ancient Murray's Lessee decision, discussed supra note 2, in insisting that the common law was a guide to the meaning of the Constitution only if "the commonlaw rule . . be one not rejected by oul ancestors as unsuited to their civil or political conditions").

115. Id. at 251. See 2 M. Pusey, Charles Evans Hughes 721 (1951) (reflecting the popular understanding that the case involved "Huey Long's tax on the . . newspapers that were opposing him").

116. 297 U.S. at 250.

117. "The tax ... is bad because, in the light of its history and of its present setting, it is seen to be a deliberate and calculated device in the guise of a tax to limit the circulation of information to which the public is entitled ...." Id. at 250.

118. Cf. Hughes I, supra note 1, at 530 (discussing United States v. Constantine, 296 U.S. 287 (1935), which struck down a federal excise tax on persons selling liquor in violation of state law because the law was based on an improper purpose).

119. Cf. Reynolds v. United States, 98 U.S. 145 (1879) (employing similar nondiscrimination test in applying first amendment ban on federal laws abridging free exercise of religion). The sugges- 
Not mentioned in Grosjean was the Court's departure from its inexplicable conclusion of thirty years before that, although corporations were "persons" within the fourteenth amendment, they enjoyed none of the "liberty" there protected.120 Justice Black was soon to attack even the accepted wisdom that corporations were "persons"; ${ }^{121}$ though unwilling to say why, the other Justices were moving in the opposite direction.

\section{Jehovah's Witnesses.}

Presbyterians, on the whole, tend to keep their religion pretty much to themselves. Jehovah's Witnesses, on the other hand, feel called upon to convince others that their way is the right one. ${ }^{122}$ In doing so, they frequently have come up against general laws enacted to secure privacy, clean and unobstructed streets, and public order. The result has been a series of decisions, beginning in the 1930s, that have helped in no small way to define the limits of constitutional protection of methods of propagating ideas. ${ }^{123}$

1. Permits. The story begins in 1938 with Lovell v. City of Griffin, ${ }^{124}$ in which the Court unanimously struck down an ordinance that

tion that the press enjoyed no blanket exemption from generally applicable laws was borne out by the opinion in Associated Press v. NLRB, 301 U.S. 103 (1937) (Roberts, J., over dissents by Sutherland, Van Devanter, McReynolds, and Butler, JJ.) that the Wagner Act's prohibition on firing employees for union activity could constitutionally be applied to a newsgathering service. Justice Roberts stated that "[t]he publisher of a newspaper has no special immunity from the application of general laws." Id. at 132-33. For justification of the distinction see Minneapolis Star \& Tribune Co. v. Minnesota Comm'r of Revenue, 460 U.S. 575, 585 (1983) (reaffirming Grosjean) ("We need not fear that a government will destroy a selected group of taxpayers by burdensome taxation if it must impose the same burden on the rest of its constituency. ... When the State singles out the press, though, the political constraints that prevent a legislature from passing crippling taxes of general applicability are weakened, and the threat of burdensome taxes becomes acute.").

120. See, e.g., Western Turf Ass'n v. Greenberg, 204 U.S. 359, 363 (1907); Northwestern Nat'l Life Ins. Co. v. Riggs, 203 U.S. 243, 255 (1906); see also Fuller I, supra note 29, at 379 n.328 (describing Riggs and Greenberg as "peculiar and unexplained"). Without noticing Grosjean, Justice Stone repeated the earlier understanding in Hague v. CIO, 307 U.S. 496, 527 (1939) (separate opinion).

121. Connecticut Gen. Life Ins. Co. v. Johnson, 303 U.S. 77, 85-90 (1938) (Black, J., dissenting). The initial decision that corporations were "persons" for fourteenth amendment purposes had been made without discussion. See Santa Clara County v. Southern Pacific R.R., 118 U.S. 394, 396 (1886).

122. See Z. Chafee, Free Speech in the United States 399 (1941) (describing the Jehovah's Witnesses as "a sect distinguished by great religious zeal").

123. See generally Barber, Religious Liberty v. Police Power: Jehovah's Witnesses, 41 AM. PoL. Sci. REV. 226 (1947) (discussing the practices of the Jehovah's Witnesses and their frequent conflicts with the law); Waite, The Debt of Constitutional Law to Jehovah's Witnesses, 28 MiNN. L. REV. 209 (1944) (crediting enlargement of constitutional liberty to propagate one's faith to the numerous Jehovah's Witness cases decided by the Supreme Court).

124. 303 U.S. 444 (1938). 
forbade distribution of literature of any kind anywhere in the city without a permit. More clearly than the injunction in Near, this was a classic previous restraint. ${ }^{125}$ History showed that freedom of the press embraced "pamphlets and leaflets" as well as "newspapers and periodicals," and that "[1]iberty of circulation [was] as essential . . a liberty of publishing; indeed, without the circulation, the publication would be of little value." 126

Chief Justice Hughes did not say in Lovell why the distribution of leaflets was not one of those "extraordinary" matters with respect to which, he had said in Near, previous restraints were permitted. He did point out that the ordinance was neither restricted "with respect to time or place" nor "limited to ways [of circulation] which might be regarded as inconsistent with the maintenance of public order or as involving disorderly conduct, the molestation of the inhabitants, or the misuse or littering of the streets."127 Whatever the evils the ordinance was designed to prevent, Hughes seemed to be saying, the measure swept altogether too broadly in achieving them.

The next year, in Schneider v. State, 128 the Court went further, striking down a licensing requirement that applied only to those who distributed literature door-to-door. Although trespasses and frauds could be forbidden directly, wrote Justice Roberts, the greater efficiency of a permit requirement did not "empower a municipality to abridge freedom of speech and press." 129

In thus begging the question, the Schneider opinion seemed to imply that the marginal benefits of the permit system were insufficient to justify its burdens on legitimate speech. Those burdens included not only the delay that inheres in all previous restraints, but also the risk of discrimination resulting from the broad terms of tle ordinance, which in the Court's view gave the police "a discretion ... to say some ideas may, while others may not, be carried to the liomes of citizens."130

125. Id. at 451-52.

126. Id. at 452 (quoting Ex parte Jackson, 96 U.S. 727, 733 (1877)); see generally D. CURRIE, supra note 4, at 442-43 (discussing Ex parte Jackson).

127. 303 U.S. at 451 .

128. 308 U.S. 147 (1939). Justice McReynolds dissented without opinion.

129. Id. at 164 .

130. Id. The ordinance, as paraphrased by the Court, required the police to refuse a permit upon finding "that the canvasser is not of good character or is canvassing for a project not free from fraud." Id. at 158. The risk of discrimination posed by such a broad grant of discretion had figured prominently in a flock of late nineteenth century state court decisions invalidating parade permit ordinances on state law grounds. See, e.g., In re Frazee's Case, 63 Mich. 396, 406-07, 30 N.W. 72, 76 (1886) ("If this were allowed ..., it would enable a mayor or council to shut off processions of those whose notions did not suit their views or tastes, in politics or religion, or any other matter on 
To this reasoning one might plausibly respond that the Court should wait to intervene until there is actual discrimination. The mere possibility that legislative authority might be misused, for example, does not outlaw its existence. The prophylactic rule adopted in Schneider, however, had been employed in the equal protection context fifty years earlier as an alternative ground in Yick Wo v. Hopkins. ${ }^{131}$ Although this rule had not shown much vitality since Yick Wo, it might have been defended in the context of Schneider as a corollary of the peculiar constitutional aversion to previous restraints: because of the importance of not delaying legitimate expression, delegations of authority to license speech must be accompanied by unusually precise standards. ${ }^{32}$

The implication that some permit requirements might be constitutional was borne out in Cox v. New Hampshire, ${ }^{133}$ which upheld the conviction of five Jehovah's Witnesses for parading on the sidewalks without a license. Traffic control, said the Chief Justice, was a legitimate state concern. The possibility of administrative abuse was strictly limited by the state court's holding that the officer issuing the permits was to consider only the effect of the proposed parade on traffic. The requirement that a permit be obtained in advance had "[t]he obvious advantage . . . [of] giving the public authorities notice ... so as to afford opportunity for proper policing." 134

The Court thus confirmed the dictum in Near that not all previous restraints were forbidden. It also confirmed the inference that the "extraordinary" situations in which such restraints were allowed were not limited to those in which there was a grave threat to national security; it sufficed that previous restraint was reasonably necessary to the impartial reconciliation of competing clamis for the use of limited resources by regulation of what the Court felicitously referred to as the "time, place

which men differ."); G. Abernathy, The Right of Assembly and Association 85-96 (2d ed. 1981).

The unexplained observation in Schneider that the opinion was "not to be taken as holding that commercial soliciting and canvassing may not be subjected to such regulation as the ordinance requires," 308 U.S. at 165 , was, perhaps, the Court's first suggestion that commercial speech might not be entitled to the same protection as political or religious speech.

131. 118 U.S. 356, 366-73 (1886). See generally D. CURR1E, supra note 4, at 387 n.134 (discussing Yick Wo's alternative holding).

132. See Currie, Der Vorbehalt des Gesetzes: Amerikanische Analogien, in V. GoTz, H. KLEIN, \& C. StaRck, Die ÖFFentliche Verwaltung zwischen Gesetzgebung und RichterLICHER KONTROLLE 68, 76-77 (1986).

133. 312 U.S. 569 (1941).

134. Id. at 576. Compare Kalven, The Concept of the Public Forum: Cox v. Louisiana, 1965 Sup. CT. Rev. 1, 26 (describing Cox as "symboliz[ing] the ideal of Robert's Rules of Order" for expression in public places) with Baker, Unreasoned Reasonableness: Mandatory Parade Permits and Time, Place, and Manner Regulations, 78 Nw. U.L. REv. 937 (1983) (taking a more critical view of Cox). 
and manner" of expression. ${ }^{135}$ Not only are impartial time, place and manner restrictions likely to serve legitimate interests unrelated to the desire to suppress information, they also leave the speaker free to convey his message in other ways.

2. Public Streets. The fact that a regulation impartially limits only the time, place and manner of expression, however, does not assure its constitutionality; the burden it places on means of communicating protected messages may be out of proportion to the strength of the countervailing governmental concern. This limitation was appropriately illustrated by another aspect of Schneider $y$. State, when the Court also struck down a collection of ordinances forbidding the distribution of handbills on public streets and sidewalks. ${ }^{136}$ "[T] streets clean and of good appearance" by preventing littering, wrote Justice Roberts, was "insufficient to justify an ordinance which prohibits a person rightfully on a public street from handing literature to one willing to receive it." 137 The unrealistic suggestion that this purpose could be achieved by "punishment of those who actually throw papers on the streets"138 was surely unnecessary to this conclusion. If the question is whether it is reasonable to weigh the risk of paper in the streets more heavily than the benefits of handbilling, the only conceivable answer is "no."139

The more interesting question, however, is whether Justice Roberts asked the right question. The city was the owner of the streets, and a generation earlier-before it had held freedom of expression applicable to the states-the Court had held in Davis v. Massachusetts that local governments did not have to allow public property to be used for the communication of ideas. ${ }^{140}$ The government-as Justice Holmes had put it for the state court in Davis - was as free to determine how its property was to be used as was any private landowner. ${ }^{141}$

135. 312 U.S. at 575. See L. Tribe, American Constitutional Law 729 (1978) ("The relative importance of the government's interests . . cannot explain the cases.").

136. 308 U.S. 147, 162-64 (1939).

137. Id. at 162 .

138. Id. See Kalven, supra note 134 , at 17 n.64 ("It is difficult to take seriously so impractical an alternative.").

139. See Z. CHAFEe, supra note 122, at 406 ("Handbills are almost the only available way for poor men to express ideas to the public or announce a protest meeting."). But see Kalven, supra note 134, at 18 (arguing that handbilling is "a method of communication of some annoyance to a majority of people so addressed" and questioning its impact on its audience).

140. 167 U.S. 43 (1897).

141. Commonwealth v. Davis, 162 Mass. $510,511,39$ N.E. 113,113 (1895), aff'd, 167 U.S. 43 (1897); cf. McAuliffe v. Mayor of New Bedford, 155 Mass. 216, 220, 29 N.E. 517,517 (1892) (no constitutional right to be a policeman). See generally D. CuRRIE, supra note 4, at $442-44$ (discussing Ex parte Jackson and Ex parte Curtis); Currie, The Constitution in the Supreme Court: Full Faith 
Holmes' argument clearly went too far. Governments, unlike private parties, are subject to constitutional limitations, and as later decisions correctly recognized, the selective denial of government benefits can both distort the market for ideas and effectively pumsh the exercise of a constitutional right.142 That was not what had happened in Schneider; the question there was whether the government could impartially deny everyone the use of the streets for the expression of ideas.

Justice Roberts treated the question lightly, saying only that "the streets are natural and proper places for the dissemination of information and opinion." ${ }^{143}$ A few months before, in Hague v. CIO, ${ }^{144}$ Roberts had reached the peculiar conclusion that the nearly forgotten privileges or immunities clause of the fourteenth amendment gave citizens the right to discuss federal legislation on the streets of Jersey City. In Hague, he had been a little more expansive:

Wherever the title of streets and parks may rest, they have immemorially been held in trust for the use of the public and, time out of mind, have been used for purposes of assembly, communicating thoughts between citizens, and discussing public questions. Such use of the streets and public places has, from ancient times, been a part of the privileges, immunities, rights, and liberties of citizens. ${ }^{145}$

All this was stated as a bald conclusion. Roberts cited no evidence to support his historical assertion, and the mere fact that the streets had traditionally been used for speech does not prove they must continue to

and the Bill of Rights, 1890-1910, 52 U. CH1. L. REv. 867, 870 n.25 (1985) [hereinafter Fuller II] (discussing Davis v. Massachusetts).

142. See, e.g., Elrod v. Burns, 427 U.S. 347 (1976) (political test for government employment). See generally Stone, Content Regulation and the First Amendment, 25 WM. \& MARY L. REV. 189 (1983) (discussing the special vices of content-based restrictions).

143. 308 U.S. at 163.

144. 307 U.S. 496 (1939).

145. Id. at 515. Only Justices Black and Hughes joined Roberts in this reasoning. Id. at 500, 532. Justices Stone and Reed, agreeing with the result, relied on the due process clause instead, without explaining how the right of expression had been infringed, thus appearing to accept Roberts' analysis under a different label. Id. at 500, 518-32. See Kalven, supra note 134, at 13 ("[I]t is not altogether clear for whom Mr. Justice Roberts was speaking ...."). Roberts' unorthodox approach seems to have been attributable to the unjustified belief that the relevant jurisdictional statute applied only to "privileges" and "immunities" despite its plain inclusion of "rights." See D. CURRIE, FEDERAL CourTs 535-38 (2d ed. 1975). Black's concurrence seems related to his later implication that it might be the privileges or immunities clause that made freedom of expression and other guarantees in the bill of rights applicable to the states. See Adamson v. California, 332 U.S. 46, 68-92 (1947) (Black, J., dissenting).

Despite Roberts' broad language about the public's right to use the streets for speech, Hague could have been decided on narrower grounds. First, like the permit decision in Sclmeider, it involved a licensing provision found to convey "arbitrary" power. Second, the court below had found that a facially absolute ban on distributing literature had been administered in a discriminatory manner. See Hague, 307 U.S. at 501, 505-06, 516. 
be. 146 Whether the streets are "held in trust for the use of the public" would seem in the first instance to be a question of state law, which in Hague was to the contrary. ${ }^{147}$ Of course it was possible that the framers of the fourteenth amendment had imposed a public trust for expression purposes that overrode state law, but Roberts' historical explication was not enough to show they had done so.

A more promising approach might have been to argue that the right to speak on public streets was so essential to the effective communication of ideas that a meaningful freedom of expression must be held to include it. ${ }^{148}$ The possible implications of this approach, however, are momentous. One might equally argue that the government must subsidize other conduct it cannot prohibit, as all rights are hollow for those who cannot afford to exercise them. If government may not forbid abortions, it must pay for them; if it may not kill a man outright, it may not let him starve.

Some support for these conclusions might be drawn from the unexplained and striking holding of Truax $v$. Corrigan 149 that the state must protect property rights from invasion by third parties. ${ }^{150}$ In accord with the eighteenth-century conception of the social compact underlying our Constitution, however, the Court has generally refused to extend Truax so far. Although the government may deprive a person of life, liberty or property by failing to protect him against other individuals, it does not do so by failing to protect him against poverty. ${ }^{151}$

The fact that denial of access to public property takes the form of a traditional prohibition inakes it easy to overlook the possible applicability of this distinction. Even if government is only prohibited from actively depriving persons of their rights, that is what it seems to have done by banning the distribution of handbills in the streets. If one looks behind the form, however, it seems clear that, like a law forbidding theft of funds from the state treasury to pay for private publication, the prohibi-

146. See Regina v. Graham, 4 T.L.R. 212, 226 (Cen. Crim. Ct. 1888) ("[U]ndoubtedly [Trafalgar] square had been used for public meetings ... . , [but] his Lordship had to say that he could find no warrant for considering that there was any right to hold meetings in Trafalgar-square, or, indeed, in any other public place.").

147. See, e.g., Thomas v. Casey, 121 N.J.L. 185, 1 A.2d 866 (1938) (New Jersey Supreme Court upholding same statute). See also Fuller I, supra note 29, at 331-34 (criticizing Illinois Cent. R.R. v. Illinois, 146 U.S. 387 (1892), for holding that state could not convey submerged land held in "public trust" without referring to state law).

148. See Stone, Fora Americana: Speech in Public Places, 1974 SuP. CT. Rev. 233, 238 (discussing Justice Roberts' dictum in Hague v. CIO, 307 U.S. 496 (1939)).

149. 257 U.S. 312 (1921).

150. Id. at 328; see also Taft, supra note 15, at 71-76.

151. See, e.g., Harris v. McRae, 448 U.S. 297, 316 (1980) (government need not pay for abortion); Currie, Positive and Negative Constitutional Rights, supra note 15, at 878 (discussing West German analogies). 
tion is a necessary means of protecting the government's right not to subsidize private expression. ${ }^{152}$

The tradition of public use of streets and parks and the aggressive form of the governmental action imvolved have helped to confine the inroads that Hague and Schneider made into the general understanding that our Constitution is one of negative rather than positive hiberties. Nevertheless, these cases stand with Truax as reminders that generalization in this area is a dangerous practice.

3. Religious Freedom. In 1940, in Cantwell v. Connecticut, ${ }^{153}$ the Court applied the techniques developed in the speech cases of Schneider and Herndon to reverse criminal convictions of Jehovah's Witnesses on grounds of religious liberty. Writing for the Court, Justice Roberts appeared to equate the tests for constitutionality of measures impinging on expression with those impinging on religion. The previous-restraint doctrine applied in Near and Lovell, however, suggested that the historical understanding of free expression comprehended exemption from regulations that could be validly apphed to noncommunicative activities. ${ }^{154}$ The history of the free-exercise clause, in contrast, was largely one of opposition to discrimination, and the Court had emphasized in its first encounter with that clause in 1898 that it gave no right to exemption from otherwise valid laws-such as those proscribing polygamy. ${ }^{155}$ Two decisions in the 1930s respecting conscientious objectors, while arguably distinguishable as involving government privileges, had tended to confirm this analysis. ${ }^{156}$

152. Cox v. New Hampshire, 312 U.S. 569, 576-77 (1941) softened the blow somewhat by holding that the state could impose a reasonable fee to cover policing and other costs incident to private use of public property. For consideration of the problems suggested by this conclusion, see Blasi, Prior Restraints on Demonstrations, 68 Mich. L. REV. 1481, 1527-32 (1970); see also Goldberger, A Reconsideration of Cox v. New Hampshire: Can Demonstrators Be Required to Pay the Costs of Using America's Public Forums?, 62 TEX. L. REv. 403, 413 (1983) (Because the public as well as the speaker benefits from use of the public forum, "a proper distribution of costs . . would allocate the costs ... to the society as a whole.").

153. 310 U.S. 296 (1940).

154. See Z. CHAFEE, supra note 122, at 400 (noting the significance of Lovell in light of the fact that "permits ... must be obtained for all sorts of activities which are thought capable of causing harm to the community").

155. See Reynolds v. United States, 98 U.S. 145, 166-67 (1878); see also D. CURRIE, supra note 4 , at 439-42.

156. In United States v. Macintosh, 283 U.S. 605 (1931) (Sutherland, J.), the Court held that naturalization might be denied on grounds of conscientious objection despite its religious basis. Chief Justice Hughes, dissenting with three others, addressed only the issue of statutory construction. Similarly, in Hamilton v. Regents of Univ. of Cal., 293 U.S. 245 (1934) (Butler, J.), the Court held that a state university might exclude students who refused military education on religious grounds. See Macintosh, 283 U.S. at 624 (dictum) ("The privilege of the native-born conscientious objector to avoid bearing arms comes not from the Constitution, but from the acts of Congress."). 
In striking down one of the two convictions in Cantwell, the Court was comfortably within the established framework of free-exercise analysis. Cantwell had been convicted for soliciting funds without a permit, and the permit was to be issued only on finding that the applicant represented a bona fide religious or charitable organization. To make the right to solicit dependent upon an administrator's "determin[ation] whether the cause is a religious one," said Roberts, was a "censorship of religion." 157 Like the permit requirement in Schneider, this provision posed an undue risk of discriminatory administration, and discrimination is at the heart of the constitutional prohibition. ${ }^{158}$

Less obvious in light of the history of the religion clause was the Court's further conclusion that Cantwell's religious freedom had been infringed by a second conviction for breach of the peace in playing an offensive phonograph record. ${ }^{159}$ On one hand, it was clear that Cantwell had been singled out because of what he had said-others apparently were free to say other things in the streets. On the other hand, it was not the religious content but rather the offensive form of the defendant's statements that had provoked his prosecution; it appears that the state was enforcing a neutral rule forbidding the use of offensive words in expressing any ideas. Thus it could be argued that the Court in Cantwell suggested for the first time that freedom of religion not only forbade discrimination against religious activities but also required religious exemptions from generally applicable laws.

It did not come to that in Cantwell itself, for the alternative holding that the conviction offended freedom of expression seemed to mean that purveyors of nonreligious messages could not have been convicted for using similarly offensive language either. ${ }^{160}$ Any suggestion that persons activated by religion were entitled to special privileges, moreover, was dramatically repudiated two weeks later in Minersville School District $v$.

157. Cantwell, 310 U.S. at 305.

158. Cf. supra notes $\mathbf{1 2 8 - 3 0}$ and accompanying text (discussing Schneider).

159. 310 U.S. at 307-11. The Court distinguished the deferential Gitlow v. New York, 268 U.S. 652 (1925), for want of a statute specifically regulating speech and revived Holmes' clear-and-present danger test to measure restrictions on both religious freedom and nonpolitical expression:

Although the contents of the [phonograph] record not unnaturally aroused animosity, we think that, in the absence of a statute narrowly drawn to define and punish specific conduct as constituting a clear and present danger to a substantial interest of the State, the petitioner's communication, considered in the light of the constitutional guarantees, raised no such clear and present menace to public peace and order as to render him liable to conviction of the common law offense in question.

310 U.S. at 311. See White, supra note 30, at 1145-51 (discussing Schenck v. United States, 249 U.S. 47 (1919)); Taft. supra note 15, at 82-91 (discussing Gitlow).

160. See Cantwell, 310 U.S. at 307 (invoking both freedom of expression and freedom of religion). 
Gobitis, 161 where Justice Frankfurter's first important constitutional opinion concluded that Jehovah's Witnesses could be required to pledge allegiance to the American flag.

If, as in the speech area, the test was whether the governmental interest could be found sufficient to justify the incursion on freedom, Justice Stone was clearly right in protesting that this decision was monstrous. ${ }^{162}$ Justice Frankfurter, however, viewed the case as presenting a claim for a special exemption from a general law assumed to be otherwise valid:

[T] he question remains whether school children, like the Gobitis children, must be excused from conduct required of all the other children in the promotion of national cohesion .... That the flag-salute is an allowable portion of a school program for those who do not invoke conscientious scruples is surely not debatable. ${ }^{163}$

The problem, as Justice Jackson would demonstrate when the Court overruled Gobitis, was with Frankfurter's assumption that the government's interest in inculcating patriotism was great enough to justify requiring anyone to pledge allegiance to the flag. ${ }^{164}$ Recognition that freedom of speech embraces the right not to speak would raise interesting line drawing problems of its own, ${ }^{165}$ but the two decisions taken together tended to confirm the established understanding that freedom of religion did not entitle the religious to special exemptions from otherwise valid laws. ${ }^{166}$

\section{CONCLUSION}

Justice Murphy's opinion for the Court in Thornhill v. Alabama, ${ }^{167}$ in 1940, appropriately sums up the developments of the Hughes period. In Thornhill, the Court, over the sole and unexplained dissent of Justice McReynolds, struck down a conviction for labor picketing on the ground

161. 310 U.S. 586,600 (1940).

162. Id. at 601-07 (Stone, J., dissenting). For a contemporaneous criticism of the decision, see Fennell, The "Reconstructed Court" and Religious Freedom: The Gobitis Case in Retrospect, 19 N.Y.U. L.Q. REv. 31 (1941).

163. 310 U.S. at $595,599$.

164. West Virginia State Bd. of Educ. v. Barnette, 319 U.S. 624, 634-36 (1943).

165. See, e.g., Abood v. Detroit Bd. of Educ., 431 U.S. 209 (1977) (compulsory payment of union dues by government employee).

166. See P. Kurland, Religion and the law of Church and State and the Supreme COURT 37-49 (1962). As Professor Kurland notes, the message of Barnette is somewhat ambiguous. Id. at 45-47. While "substantially in agreement" with Jackson's "opinion of the Court," Justices Black and Douglas explained their concurrence on freedom of religion grounds. Barnette, 319 U.S. at 643-44. Justice Murphy appeared to embrace both theories, 319 U.S. at 644-46, and three dissenters in two different dissents thought the flag salute constitutional, 319 U.S. at 642-43 (Roberts and Reed, JJ., dissenting); 319 U.S. at 646-71 (Frankfurter, J., dissenting).

167. 310 U.S. 88 (1940). 
that the statute under which the defendant had been prosecuted infringed freedom of expression. ${ }^{168}$ Several facets of this opinion reflect the jurisprudence that had developed in the 1930s.

First, as in Stromberg, the Court condemned the statute as overbroad on its face. An overbroad statute, like the broad permit standard in Schneider, "readily lends itself to harsh and discriminatory enforcement" and "sweeps within its ambit other activities that in ordinary circumstances constitute an exercise of freedom of speech or of the press." Moreover, there were "special reasons" for insisting that the statute itself be beyond reproach when freedom of expression was concerned. ${ }^{169}$

Second, as it had done without discussion in holding that freedom of expression extended to religious speech in the Jehovah's Witnesses cases, the Court in Thornhill gave broad scope to the types of expression protected. Despite an earlier suggestion that purely commercial speech might be excluded from first amendment protection, the Court held that labor picketing was included because it dealt with matters of public concern. ${ }^{170}$

Third, as in Schneider, the Court reaffirmed that the Constitution placed limits even on measures that restricted only the time, place and manner of conveying messages, repeating Schneider's conclusion that "one is [entitled] not to have the exercise of his liberty of expression in appropriate places abridged on the plea that it may be exercised in some other place."171 Indeed, as a companion case makes clear, Thornhill may be said to have reaffirmed Stromberg's silent holding that freedom of expression was not limited to the written or spoken word, because picketing entails expression in part through physical presence. ${ }^{172}$

168. Id. at 101-06.

169. Id. at $97-98$ (emphasizing relation between overbreadth and previous restraint doctrines).

170. See id. at 102-04 ("Free discussion concerning the conditions in industry and the causes of labor disputes appears to us indispensable to the effective and intelligent use of the processes of popular government to shape the destiny of modern industrial suciety."). Compare id. with Schneider v. State, 308 U.S. 147, 163-65 (1939) (suggesting commercial speech not protected).

171. 310 U.S. at 506 (quoting Schneider, 308 U.S. at 163). See also Mendelson, Clear and Present Danger-from Schenck to Dennis, 52 Colum. L. REv. 313, 318 (1952) (“Thornhill . . . made explicit what Mr. Justice Holmes had only implied, namely, that a regulaton of the manner of expression may in some circumstances be a serious impediment to ideas themselves.").

172. See Carlson v. California, 310 U.S. 106, 112-13 (1940) (Murphy, J.,) ("The carrying of signs and banners, no less than the raising of a flag, is a natural and appropriate means of conveying information on matters of public concern."); Henkin, supra note 90, at 79 ("In picketing, ... it is not solely or primarily the words that communicate; the presence of the pickets is itself a communication, and indeed picketing is often effective regardless of what the placards say, because even persons who never read the placards are reluctant to cross a picket line."); see also Teller, Picketing and Free Speccl, 56 Harv. L. Rev. 180, 200-08 (1942) (arguing that picketing is not persuasion but "a form of economic pressure"); Dodd, Picketing and Free Speech: A Dissent. 56 HARv. L. Rev. 513, 517 
Fourth, as in Cantwell, the Court expressly revived the clear-andpresent danger test that Holmes had enunciated for the Court in the political context in Schenck $v$. United States. ${ }^{173}$ It did so, moreover, while striking down a statute specifically directed toward speech, contrary to the apparent thrust of Gitlow v. New York. ${ }^{174}$ In applying that test, Justice Murphy reasonably concluded that the danger of violence from labor picketing did not justify a blanket ban, just as the danger of littering had not justified the handbilling prohibition in Schneider. ${ }^{175}$ By stressing the inportance of picketing and the trivial nature of the interest in preventing litter, however, the Court in each case seemed to suggest that the clear-and-present danger formula did not entirely capture what the Justices were actually doing. In response to the nature of the problem it was atteinpting to solve, the Court seemed to be weighing the need for regulation against the degree of incursion on the interest in communication; whether the relevant dangers were clear or present was only part of that inquiry. ${ }^{176}$

Finally, Justice Murphy confirmed the obvious impression that measures impinging on freedom of expression were now being scruti-

(1943) (responding that picketing "is generally the only practicable method of communicating the ideas which [labor unions] wish to express to the person to whom they wish to express them").

173. 310 U.S. at 104-05 ("Abridgment of the liberty of such discussion can be justified only where the clear danger of substantive evils arises under circumstances affording no opportunity to test the merits of ideas by competition for acceptance in the market of public opinion. We hold that the danger of injury to an industrial concern is neither so serious nor so imminent as to justify the sweeping proscription of freedom of discussion embodied in [the statute]."); see supra text accompanying notes 153-60 (discussing Cantwell).

174. See 268 U.S. at $670-71$; Taft, supra note 15 , at $85-86$.

175. See 310 U.S. at 105 ("[N]o clear and present danger of destrnction of life or property, or invasion of the right of privacy, or breach of the peace can be thought to be inherent in the activities of every person who approaches the premises of an employer and publicizes the facts of a labor dispute involving the latter."). Cf. supra notes 128-30 and accompanying text (discussing Schneider). In one respect Thornhill was in fact the easier of the two cases, for the picketing ban was not neutral as to the content of speech; it forbade picketing only for the purpose of discouraging others from dealing with the owner of the premises or of injuring his business. 310 U.S. at 91 .

176. In the brief time remaining before Chief Justice Hughes left the Court, the Justices began to grapple with the difficult problems presented by labor injunctions under rules more narrowly tailored to preventable evils than was the statute in Thornhill. In so doing the Justices revealed disagreements concealed by the relatively easy speech cases of the 1930s that would make the ensuing period one of deep disagreement over the degree of scrutiny of state measures affecting expression. See Milk Wagon Drivers Union v. Meadowmoor Dairies, Inc., 312 U.S. 287, 292, 294 (1941) (Frankfurter, J., over dissents by Black, Douglas, and Reed, JJ.) (injunction against peaceful picketing allowed because past picketing had been so "enmeshed with contemporaneously violent conduct" that "it could justifiably be concluded that the momentum of fear generated by past violence would survive even though future picketing might be wholly peaceful"). The contrast with Near $v$. Minnesota, 283 U.S. 897 (1931), where past publications assumed to be punishable had been held not to justify an injunction even against defamatory publications, was striking. See 312 U.S. at 319 (Reed, J., dissenting) ("If the fear engendered by past misconduct coerces storekeepers during peaceful picketing, the remedy lies in the maintenance of order, not in denial of free speech."). 
nized far more strictly than those limiting purely economic interests, ${ }^{177}$ and he explained why: "A.bridgment of freedom of speech and of the press ... impairs those opportunities for public education that are essential to effective exercise of the power of correcting error through the processes of popular government." 178 Appropriately, he cited at this point Justice Stone's celebrated footnote in United States v. Carolene Products Co., ${ }^{179}$ which had suggested closer scrutiny of measures limiting participation in the formulation of policy as well as of those touching rights specifically listed in the first eight amendments or affecting discrete and insular minorities. In so saying, Stone had perceptively charted the course of constitutional litigation for the ensuing fifty years.

In abandoning the old limits on economic regulation, the Court under Hughes cleared the way for undivided attention to the new agenda. By holding first amendment freedoms applicable to the states, adding to the procedural components of due process, and closely scrutinizing allegations of racial discrimination, it made a significant start in dealing with that agenda. ${ }^{180}$ In establishing the basic contours of the doctrines of previous restraint, overbreaclth, symbolic speech, time, place and manner regulations, and the public forum, while showing new vigor in protecting political utterances, the Court erected the framework on which the modern law of free expression rests.

177. 310 U.S. at 95. Thornhill dramatically illustrated the change of focus by holding that the Constitution forbade a limitation on picketing that the Court had once found to be constitutionally required. See Truax v. Corrigan, 257 U.S. 312, 328 (1921); Taft, supra note 15, at 71-76.

178. 310 U.S. at 95 . Justice Murphy added, without a trace of the deference that had characterized recent substantive due process decisions in the economic sphere, see Hughes I, supra note 1. at 507-10, that "[m]ere legislative preference for one rather than another means for combatting substantive evils ... may well prove an inadequate foundation on which to rest regulations which are aimed at or in their operation diminish the effective exercise of rights so necessary to the maintenance of democratic institutions." 310 U.S. at 95-96.

179. United States v. Carolene Prods. Co., 304 U.S. 144, 152-53 n.4 (1938); see Hughes I, supra note 1 , at 554-55.

180. See R. MCCloskey, supra note 38, at 169-79. 